\title{
SYNTHESIS OF SORBITOL BY ZYMOMONAS MOBILIS UNDER HIGH OSMOTIC PRESSURE
}

\author{
Márcio de Barros; Maria Antonia Pedrine Colabone Celligoi* \\ Departamento de Bioquímica e Biotecnologia, Universidade Estadual de Londrina. Londrina, PR, Brasil \\ Submitted: July 12, 2005; Returned to authors for corrections: October 06, 2005; Approved: June 14, 2006
}

\begin{abstract}
The bacterium Zymomonas mobilis presents potential for sorbitol production when grown in culture medium with high sugar concentration. Sorbitol is produced and accumulated in the periplasma of the bacterium to protect the cells from the harmful effects of high osmotic pressure that results from the action of invertase on sucrose. The conversion of sucrose into glucose and fructose increases the osmolarity of the medium. However, an excessive increase in the osmotic pressure may decrease the sorbitol production. In this work Saccharomyces cerevisiae invertase was added two media containing sucrose 200 and 300 g.L. ${ }^{-1}$. Sorbitol production in sucrose at $200 \mathrm{~g} . \mathrm{L}^{-1}$ was 42.35 and $38.42 \mathrm{~g} . \mathrm{L}^{-1}$, with and without the invertase treatment, respectively. In the culture medium with $300 \mathrm{~g} . \mathrm{L}^{-1}$ sucrose, production reached $60.4 \mathrm{~g} . \mathrm{L}^{-1}$ and with invertase treatment was 19.14 g. $\mathrm{L}^{-1}$. These results indicated that the excessive rise in osmotic pressure led to a significant decrease in sorbitol production by the Zymomonas mobilis bacterium in the sucrose medium treated with invertase.
\end{abstract}

Key words: Zymomonas mobilis, invertase, osmotic pressure, sorbitol

\section{INTRODUCTION}

Sorbitol is a polyol with a sweet and refreshing flavor, and can be used as sweetener, moisturizer, texturizer and softener in the food industry. Other uses include vitamin C, sorbose, glycerol propylene, plastics and resin production. Sorbitol can be used in dietetic foods for diabetics because it is not insulindependent $(6,17)$.

World sorbitol production has been estimated to be more than 500.000 ton per year, traditionally from glucose catalytic hydrogenation using nickel as the catalyzer, at high pressures and temperatures. After the catalytic hydrogenation process, the sorbitol is collected and purified, making the process expensive $(6,8)$. However, other methods can be used to obtain sorbitol, such as the biotechnological process by fermentation.

The Zymomonas mobilis bacterium has been the target of much research mainly because it presents potential for ethanol and by-product production (including sorbitol, gluconic acid and fructooligosaccharides) when the culture medium contains high sugar concentrations $(5,16,21)$. According to Bekers et al. (2) and Sprenger (19), sorbitol production by Zymomonas mobilis occurs by the glucose-fructose oxidoreductase enzyme (GFOR) present in the bacterium periplasm that simultaneously converts the glucose and fructose to glucono- $\delta$-lactone and sorbitol, respectively. Silveira and Jonas (17) reported in their review that GFOR has a very important physiological function for the bacterium, because the sorbitol produced is accumulated by the microorganism to prevent the harmful effects caused by high osmotic pressures of the cell when grown on high sugar concentration in the fermentation medium.

Researchers have studied the effect of osmotic pressure on the production and excretion of microbial metabolites including sorbitol, ethanol, gluconic acid, glycerol. Liu et al. (13) studied the effect of osmotic pressure on glycerol production by Candida krusei, using glucose to raise the osmolarity of the medium and detected that increase in osmotic pressure produced an increase in glycerol production by the microorganism. Wu et al. (22) cultured Panax ginseng cells in a culture medium with

*Corresponding Author. Mailing address: Departamento de Bioquímica e Biotecnologia, CCE, Universidade Estadual de Londrina, Caixa Postal 6001. 86051-990, Londrina, PR, Brasil. Tel.: (+5543) 3371-4270. E-mail: macelligoi@uel.br 
high osmotic pressure to produce saponin and concluded that the high pressure of the culture medium decreased cell growth, but increased secondary metabolite production by the cells.

The effect of osmo-induced stress on product formation by Zymomonas mobilis was studied by Bekers et al. (3). The authors induced an increase in sorbitol production in the presence of $0.16 \mathrm{M} \mathrm{NaCl}$ that was inhibited at the highest salt concentration. Lin et al. (12) used different glycerol concentrations in the fermentation medium to cause an increase in osmolarity and obtained negative effects in cell growth and ethanol production by Zymomonas mobilis. Crittenden et al. (4); Lee et al. (11); Lee et al. (10); Takeshige and Ouchi (20) also studied Zymomonas mobilis and used yeast invertase in the fermentation medium containing sucrose to promote sucrose hydrolysis into glucose plus fructose, consequently increasing the osmotic pressure of the medium and ethanol production by Zymomonas mobilis.

Osmotic pressure is one of the preponderant factors in sorbitol production by Zymomonas mobilis and the treatment of the medium with invertase can cause this effect, by increasing the reducing sugar concentration in the fermentation medium. The main objective of this study was to investigate sorbitol production by Zymomonas mobilis in sucrose medium with and without invertase treatment.

\section{MATERIALS AND METHODS}

\section{Microorganism and preservation}

The microorganism used in this study was the bacterium Zymomonas mobilis ATCC 29191, preserved in medium containing (in g. L ${ }^{-1}$ ): 100 glucose; 10.0 yeast extract; 2.0 $\left(\mathrm{NH}_{4}\right)_{2} \mathrm{SO}_{4} ; 3.0 \mathrm{KH}_{2} \mathrm{PO}_{4} ; 0.3 \mathrm{Mg} \mathrm{SO} \mathrm{S}_{4} . \mathrm{H}_{2} \mathrm{O} ; 5.0$ peptone; 0.2 $\mathrm{FeSO}_{4}$. After incubation for 24 hours at $30^{\circ} \mathrm{C}$, the cultures were kept at $4^{\circ} \mathrm{C}$ and reactivated every 30 days.

\section{Invertase}

Invertase was extracted from baker's yeast, Saccharomyces cerevisiae, according to Nepomuceno (16), kept in a refrigerator at $4^{\circ} \mathrm{C}$ with an activity of $6400{\mathrm{U} . \mathrm{g}^{-1}}^{-1}$.

\section{Fermentation and media}

Medium I - sucrose at 200 g.L $L^{-1}$ of total reducing sugar (TRS); medium II - sucrose at 200 g. $\mathrm{L}^{-1}$, treated with invertase; medium III - 300 g.L.- ${ }^{-1}$ sucrose of TRS; medium IV - sucrose at 300 g.L. $\mathrm{L}^{-1}$ pre-treated with invertase. Medium preservation without glucose was used for all the fermentation media. The sucrose medium was treated with invertase for a period of three hours with agitation at $28^{\circ} \mathrm{C}$. The invertase ratio used was $1: 50 \mathrm{~mL}$ ( $1 \mathrm{~mL}$ invertase and $50 \mathrm{~mL}$ fermentation medium).

\section{Fermentations}

The experiments were carried out in $250 \mathrm{~mL}$ Erlenmeyer flasks with $50 \mathrm{~mL}$ of the I, II, III or IV media at $30^{\circ} \mathrm{C}$, static culture, for periods of 12 and 36 hours with initial $\mathrm{pH}$ 6.0. The inoculum was standardized at $0.2 \mathrm{~g} . \mathrm{L}^{-1}$ for all the experiments. The process was monitored by quantifying the biomass, sugar consumption, and sorbitol and ethanol production. The experiments were carried out in duplicate.

\section{Analytical methods}

Reducing sugars (RS) and total reducing sugars (TRS) were quantified by the Somogy (18) and Nelson (15) method. Total reducing sugars (TRS) were determined after acid hydrolysis with $\mathrm{HCl}$ at $1 \mathrm{~N}$ according to Amorim (1). The biomass was determined spectrophotometrically at $\lambda=605 \mathrm{~nm}$ and related to a calibration biomass curve. Sorbitol concentration was quantified by high efficiency liquid chromatography (HPLC) using an aminex HPX $87 \mathrm{C}$ column $(300 \mathrm{~mm} \mathrm{X} 7.8 \mathrm{~nm})$, at $55^{\circ} \mathrm{C}$, with water as eluent $(1 \mathrm{~mL} / \mathrm{min})$ and a refraction index detector. The ethanol contents were determined by the Kaye and Haag method (9). The osmolarity was determined using osmometer cryoscopy (Gonotec, Osmomat 30) and the osmotic pressure was determined according to Guyton and Hall (7). The results were submitted to the Tukey test at the $5 \%$ level of significance.

\section{RESULTS AND DISCUSSION}

\section{Sorbitol and ethanol production by Zymomonas mobilis in sucrose medium at 200 g. $\mathrm{L}^{-1}$}

The results of sorbitol and ethanol production by Zymomonas mobilis in sucrose medium at $200 \mathrm{~g} . \mathrm{L}^{-1}$ are shown in Table 1.

The results in Table 1 show that in medium I the highest sorbitol production was 42.35 g.L. $\mathrm{L}^{-1}$, with $190.91 \mathrm{~g} . \mathrm{L}^{-1}$ sugar consumption in the $36 \mathrm{~h}$ culture time and $1.18 \mathrm{~g} / \mathrm{L} \mathrm{h}^{-1}$ sorbitol productivity. In medium II, the fermentation process started with 160.54 g.L $\mathrm{L}^{-1}(\mathrm{RS})$, that were made available by hydrolysis of the sucrose by invertase and the highest sorbitol production was at $36 \mathrm{~h}$, reaching 38.42 g.L $\mathrm{L}^{-1}$ with $189.76 \mathrm{~g} . \mathrm{L}^{-1}$ sugar consumption and $1.05 \mathrm{~g} / \mathrm{L} \mathrm{h}^{-1}$ productivity.

The statistical analysis showed that sorbitol production in sucrose media with and without treatment with invertase did not present significant differences in the 12 or $36 \mathrm{~h}$ culture time, indicating that the treatment with invertase did not alter sorbitol production by Zymomonas mobilis.

Lee and Huang (10) studied sucrose media at $200 \mathrm{~g} . \mathrm{L}^{-1}$ with and without invertase treatment demonstrating that in the media where the sucrose was not hydrolyzed previously, a production of 24.30 g.L. $\mathrm{L}^{-1}$ of sorbitol was obtained in the 24 culture time, and in the previously hydrolyzed medium sorbitol production decreased to 15.70 g.L $\mathrm{L}^{-1}$. According to the authors, previous sucrose hydrolysis delayed the formation of some byproducts by Zymomonas mobilis.

Takeshige and Ouchi (20) also reported the negative effect of invertase on ethanol production in sugarcane molasses. They 
Table 1. Sugar consumption and ethanol, sorbitol and biomass production by Zymomonas mobilis in sucrose at $200{\mathrm{~g} . \mathrm{L}^{-1}}^{-1}$ (I) and in sucrose at 200 g.L ${ }^{-1}$ treated with invertase (II); sucrose at 300 g.L ${ }^{-1}$ (III) and in sucrose at 300 g.L.- trated with invertase (IV).

\begin{tabular}{ccccccccc}
\hline Media & Time $(\mathrm{h})$ & $(\mathrm{RS})\left(\mathrm{g} . \mathrm{L}^{-1}\right)$ & $(\mathrm{TRS})\left(\mathrm{g} . \mathrm{L}^{-1}\right)$ & $\begin{array}{c}\text { Sugar } \\
\text { Consumption } \\
\left(\mathrm{g} . \mathrm{L}^{-1}\right)\end{array}$ & $\begin{array}{c}\text { Ethanol } \\
\left(\mathrm{g} . \mathrm{L}^{-1}\right)\end{array}$ & $\begin{array}{c}\text { Sorbitol } \\
\left(\mathrm{g} . \mathrm{L}^{-1}\right)\end{array}$ & $\begin{array}{c}\text { Biomass } \\
\left(\mathrm{g} . \mathrm{L}^{-1}\right)\end{array}$ & $\begin{array}{c}\text { Osmotic } \\
\text { pressure } \\
(\mathrm{mmHg})\end{array}$ \\
\hline I & 0 & 0.75 & 229.90 & 0 & 0 & 0 & 0.20 & 14436.40 \\
I & 12 & 131.17 & 176.66 & 53.25 & $14.18 \pm 0.89^{\mathrm{b}}$ & $19.57 \pm 3.66^{\mathrm{c}}$ & 1.11 & \\
I & 36 & 10.77 & 37.29 & 190.91 & $54.88 \pm 0.88^{\mathrm{a}}$ & $42.35 \pm 2.41^{\mathrm{b}}$ & 2.07 & \\
II & 0 & 160.54 & 229.90 & 0 & 0 & 0 & 0.20 & 22349.40 \\
II & 12 & 180.78 & 189.76 & 40.14 & $1.53 \pm 0.21^{\mathrm{c}}$ & $8.39 \pm 0.18^{\mathrm{d}}$ & 0.44 & \\
II & 36 & 29.85 & 49.80 & 180.01 & $49.01 \pm 1.96^{\mathrm{a}}$ & $38.42 \pm 0.68^{\mathrm{b}}$ & 1.83 & \\
III & 0 & 3.31 & 335.64 & 0 & 0 & 0 & 0.20 & 20226.40 \\
III & 12 & 106.09 & 290.16 & 45.48 & $2.65 \pm 0.59^{\mathrm{c}}$ & $13.25 \pm 2.41^{\mathrm{c}}$ & 0.65 & \\
III & 36 & 87.32 & 157.76 & 177.92 & $55.38 \pm 8.45^{\mathrm{a}}$ & $60.42 \pm 3.83^{\mathrm{a}}$ & 1.96 & \\
IV & 0 & 144.62 & 335.64 & 0 & 0 & 0 & 0.20 & 27460.40 \\
IV & 12 & 166.69 & 316.94 & 23.20 & $0.4 \pm 0.0^{\mathrm{c}}$ & $11.51 \pm 1.25^{\mathrm{c}}$ & 0.37 & \\
IV & 36 & 177.60 & 302.05 & 33.59 & $9.90 \pm 2.23^{\mathrm{b}}$ & $19.14 \pm 1.17^{\mathrm{c}}$ & 0.81 & \\
\hline
\end{tabular}

Media with the same letters do not differ for $\mathrm{p} \leq 0.05$.

explained that invertase is a potent osmotic regulator, that causes sucrose hydrolysis in glucose and fructose increasing the osmolarity of the medium. Consequently there was an increase in the osmotic pressure that inhibited cell growth, reducing sorbitol and ethanol production by the bacterium.

In the present study, medium I with 200 g.L. L $^{-1}$ sucrose presented an osmotic pressure of approximately $14436.40 \mathrm{mmHg}$. When the medium was previously hydrolyzed with invertase, medium II, the osmotic pressure increased to $22349.40 \mathrm{mmHg}$. This increase in the osmotic pressure by hydrolysis of the sucrose medium with invertase reduced sorbitol synthesis, but this reduction was not significant for this condition. The same occurred with ethanol production, where the highest value occurred in medium I with the production of 54.88 g.L $\mathrm{L}^{-1}$, but it was not significantly different from medium II where ethanol production reached 49.01 g.L-1 .

\section{Sorbitol and ethanol production by Zymomonas mobilis sucrose medium at 300 g. $\mathrm{L}^{-1}$}

Significant difference was observed in sugar consumption, sorbitol, and ethanol and biomass production by Zymomonas mobilis when grown in sucrose at $300 \mathrm{~g} . \mathrm{L}^{-1}$ sucrose medium and sucrose treated with invertase, (media III and IV, respectively). The results are shown in Table 1.

Table 1 shows that the highest and statistically significant sorbitol production occurred in medium III in the $36 \mathrm{~h}$ culture time with a production of $60.46 \mathrm{~g} . \mathrm{L}^{-1}$ and $1.68 \mathrm{~g} / \mathrm{Lh}^{-1}$ productivity. The highest ethanol production also occurred in medium III at $36 \mathrm{~h}$, with a production of $55.38 \mathrm{~g} \cdot \mathrm{L}^{-1}$ and $1.59 \mathrm{~g} / \mathrm{L} \cdot \mathrm{h}^{-1}$ productivity. When the media was previously hydrolyzed with invertase, fermentation began at $144.62 \mathrm{~g} . \mathrm{L}^{-1}$ available reducing sugar and the sorbitol production fell to 19.14 g.L. ${ }^{-1}$ with $0.53 \mathrm{~g} /$ L.h ${ }^{-1}$ productivity and ethanol production decreased to 9.90 g.L ${ }^{-1}$ with $0.28 \mathrm{~g} / \mathrm{L} \cdot \mathrm{h}^{-1}$ productivity.

A significant decrease in sorbitol and ethanol production by Z. mobilis was observed when medium III was compared with medium IV, probably due to the excessive increase in osmotic pressure. In medium III, the initial osmotic pressure was approximately $20226.40 \mathrm{mmHg}$ and the cellular growth reached 1.96 g. $\mathrm{L}^{-1}$, while in medium IV osmotic pressure was 27460.40 $\mathrm{mmHg}$ but cell growth was only $0.81 \mathrm{~g} . \mathrm{L}^{-1}$, indicating that the excessive increase in pressure inhibited bacterial growth and consequently decreased sorbitol and ethanol production by $Z$. mobilis. This proved the negative effect of the excessive increase in osmotic pressure in the fermentation medium reported by Takeshige and Ouchi (20), demonstrating that the addition of highly active invertase decreased ethanol production because the excessive increase in osmolality, due to monosaccharide supply that was not well balanced with their consumption, so that the high osmolality in the medium remained.

Loss et al. (14) reported in their study that GFOR, present in the periplasm space of the bacterium, restrict sorbitol formation to conditions of osmotic stress. Because of its extraordinarily low affinity to fructose ( $K m 400 \mathrm{mM}$ to $1 \mathrm{M}$ ), sorbitol is formed at appreciable rates only when cells encounter high fructose concentrations. Glucose is the preferred substrate of the glucose facilitator in Z. Mobilis outcompeting fructose. When Z. mobilis grown in medium with access to both substrates (glucose plus 
fructose) fructose is not primarily transported but can be utilized to form fructo-oligomers or levan, consequently decreasing the sorbitol production.

Fig. 1 compares the results of sorbitol production in the media tested, and demonstrates the negative effect of excessive increase in osmotic pressure caused by yeast invertase in sorbitol production by Zymomonas mobilis.

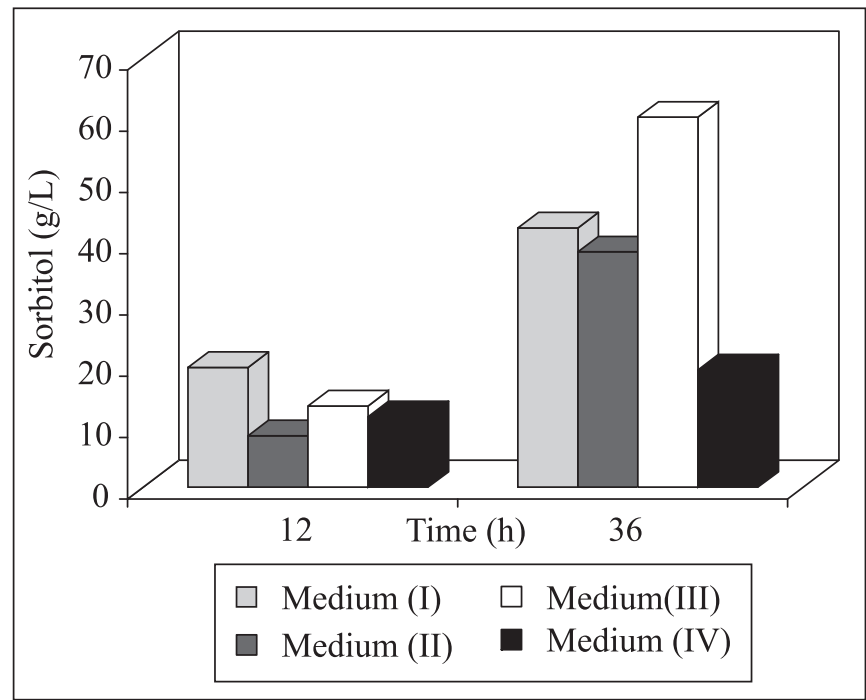

Figure 1. Sorbitol production by Zymomonas mobilis, in sucrose at 200 g.L $\mathrm{L}^{-1}$ (I) and in sucrose at $200 \mathrm{~g} . \mathrm{L}^{-1}$ treated with invertase (II); sucrose at 300 g.L $\mathrm{L}^{-1}$ (III) and in sucrose at 300 g.L $\mathrm{L}^{-1}$ trated with invertase (IV).

\section{CONCLUSION}

The best medium obtained in this study for sorbitol production was medium III, sucrose at $300 \mathrm{~g}$. $\mathrm{L}^{-1}$. The best ethanol production was also obtained in medium III, but it did not differ significantly from media I and II. The treatment of the sucrose medium at $300 \mathrm{~g} . \mathrm{L}^{-1}$ with invertase significantly decreased sorbitol and ethanol production due to the excessive increase in osmotic pressure.

\section{RESUMO}

\section{Síntese de sorbitol por Zymomonas mobilis sob elevada pressão osmótica}

A bactéria Zymomonas mobilis, apresenta potencial para produção de sorbitol quando crescida em meio com alta concentração de açúcar. O sorbitol produzido é acumulado no periplasma da bactéria para conter os efeitos prejudiciais da elevada pressão osmótica, que resulta pela ação da enzima invertase, que promove hidrólise da sacarose. A conversão da sacarose em glicose e frutose aumentando a osmolaridade do meio. Entretanto, um aumento excessivo na pressão osmótica pode inibir a produção de sorbitol pela bactéria. Este trabalho empregou invertase de Saccharomyces cerevisiae nos meios de fermentação com sacarose a $200 \mathrm{e} 300 \mathrm{~g}$. L $\mathrm{L}^{-1}$. A produção de sorbitol no meio com sacarose a $200 \mathrm{~g}$. L $\mathrm{L}^{-1}$ foi de $42,35 \mathrm{~g}$. L $\mathrm{L}^{-1} \mathrm{e}$ $38,42 \mathrm{~g} \mathrm{~L}^{-1}$ com e sem tratamento com invertase respectivamente. No meio com $300 \mathrm{~g}$. L $\mathrm{L}^{-1}$ sem tratamento, a produção foi de 60,42 e com tratamento $19,14 \mathrm{~g}$. $\mathrm{L}^{-1}$. Estes resultados indicaram que a elevação excessiva da pressão osmótica, pela adição de invertase levou a uma diminuição significativa na produção de sorbitol pela bactéria Zymomonas mobilis.

Palavras-chave: Zymomonas mobilis, invertase, pressão osmótica, sorbitol

\section{REFERENCES}

1. Amorim, H.V.; Zago, E.A.; Oliveira, A.J. Novos métodos analíticos para controle de fermentação alcoólica. SBM, São Paulo, 1982, $58 \mathrm{p}$.

2. Bekers, M.; Laukevics, L.; Karsakevich, A.; Ventina, E.; Kaminska, E.; Upit, D.; Vina, I.; Linde, R.; Scherbaka, R. Levanethanol biosynthesis using Zymomonas mobilis cells immobilized by attachment and entrapment. Process. Biochem., 36, 979 986, 2001.

3. Bekers, M.; Vigants, A.; Laukevics, J.; Toma, M.; Rapoports, A.; Zkmanis, P. The effect of osmo-induced stress on product formation by Z. mobilis on sucrose. Int. J. Food Microbiol., 55,147-150, 2000.

4. Critenden, R.G.; Playne, M.J. Purification of food-grad oligosaccharides using immobilized cells of Zymomonas mobilis. Appl. Microbiol. Biotechnol., 58, 297-302, 2002.

5. Doelle, H.W.; Kirk, L.; Crittenden, R.; Toh, H. Zymomonas mobilis - Science and industrial application. Crit. Rev. Biotechnol., 13(1), 57-98, 1993.

6. Erzinger, G.S.; Silveira, M.M.; Costa, J.P.C.L.; Vitolo, M.; Jonas, R. Activity of glucose-fructose oxidoreductase in fresh and permeabilised cells of Zymomonas mobilis grown in different glucose concentrations. Braz. J. Microbiol., 34, 329-333, 2003.

7. Guyton, A.C.; Hall, J.E. Medical Physiology. Mississipi, 2000, 1064p.

8. Gorp, V.K.; Boerman, E.; Cavenaghi, C.V.; Berben, P.H. Catalytic hydrogenation of fine chemicals: sorbitol production. Catalysis today., 52, 349-361, 1999.

9. Kaye, S.; Haag, H.B. Determination of ethyl alcohol in blood. $J$ Forensic Med., 1, 373-381, 1954.

10. Lee, W.C.; Huang, C.T. Enhancement of ethanol production from sucrose by Zymomonas mobilis by the addition of immobilized invertase. Enzyme Microb. Technol., 17, 79-84, 1995.

11. Lee, W.C.; Huang, C.T. Modelling of ethanol fermentation using Zymomonas mobilis ATCC 10988 grown on the media containing glucose and fructose. Biochem. Eng. J., 4, 217-227, 2000.

12. Lin, J.J.; Dale, M.C.; Okos, M.R. Osmotic $\left(\mathrm{a}_{\mathrm{w}}\right)$ effects on growth and ethanol production of free and immobilized Zymomonas mobilis. Process Biochem., 26, 143-151, 1991.

13. Liu, Y.; Liu, D.; Su, Q.; Liu, J.; Xie, D. Critical influence of osmotic pressure on continuous production of glycerol by an osmophilic strain of Candida Krusei in a multistage cascade bioreactor. Process. Biochem., 38, 427-432, 2002. 
14. Loos, H.; Krämer, H.S.; Sprenger, G.A. Sorbitol promotes growth of Zymomonas mobilis in evironments with high concentration of sugar: Evidence for a physiological function of glucose-frutctose oxidoreductase in osmoprotection. J. Bacteriol., 176(24), 76887693, 1994

15. Nelson, N. A photometric adaptation of the Somogyi method for determination of glucose. Biochemical, 153, 375-380, 1944.

16. Nepomuceno, M.F. Cinética enzimática II: Cinética enzimática da invertase. In:

Bioquimíca experimental. Piracicaba UNIMEP, 1998, p.57-60. Piracicaba, 1998, p.57-60.

17. Silveira, M.M.; Jonas, R. The Biotechnological production of sorbitol. Appl. Microbiol. Biotechnol., 59, 400-408, 2002.

18. Somogy, M.A. A new reagent for determination of sugar. J. Biol. Chem., 160, 61-68, 1945.
19. Sprenger, G.A. Carbohydrate metabolism in Zymomonas mobilis: a catabolic highway with some scenic routes. FEMS Microbiol. Lett., 145, 301-307, 1996.

20. Takeshige, Z.; Ouchi, K. Effect of yeast invertase en ethanol production in molasses. J. Ferment. Bioeng., 79, 513-515, 1995.

21. Toma, M.M.; Kalnenieks, U.; Berzings, A.; Vigants, A.; Rikmanis, M.; Viesturs, U. The effect of mixing on glucose fermetation by Zymomonas mobilis continuous culture. Process. Biochem., 38, 1347-1350, 2003.

22. Wu, J.Y.; Wong, K.; Ho, K.P.; Zhou, L.G. Enhancement of saponin production in Panax ginseng cell culture by osmotic stress and nutrient feeding. Enzyme Microb. Technol., 6(1), 133-138, 2005. 